\title{
The role of a cascade of reservoirs and seasonal variation in the phytoplankton structure in a tropical river
}

\author{
Moura, AN. ${ }^{a *}$, Severiano, JS. ${ }^{a}$, Tavares, NKA. ${ }^{a}$ and Dantas, $E W^{b}$ \\ aÁrea de Botânica, Departamento de Biologia, Universidade Federal Rural de Pernambuco - UFRPE, \\ Rua D. Manoel de Medeiros, s/n., Dois Irmãos, CEP 52171-030, Recife, PE, Brazil \\ ${ }^{\text {b}}$ Departamento de Ciências Biológicas, Centro de Ciências Biológicas e Sociais Aplicadas - CCBSA, Universidade \\ Estadual da Paraíba - UEPB, Campus V, Rua Horácio Trajano, s/n., Cristo, CEP 58070-450, João Pessoa, PB, Brazil \\ *e-mail: ariadne@db.ufrpe.br; ariadne_moura@hotmail.com
}

Received June 5, 2012 - Accepted July 24, 2012 - Distributed May 31, 2013

(With 3 figures)

\begin{abstract}
This study aims to analyse the influence of a cascade of reservoirs on the density, richness and functional groups of phytoplankton in the Contas River, a tropical river of Brazil. This river has two dams along its course, forming the Pedra and Funil reservoirs. Samples were collected over three consecutive years (Dec., 2007 to Dec., 2010) at 28 sampling stations along the river. We identified 198 species and the stretches downstream from the reservoirs showed greater richness. Chlorophyceae, followed by Bacillariophyceae and Cyanophyceae were the dominant groups and highest density was recorded during the rainy season. Overall, a longitudinal pattern in algal densities was found for both seasons, with the lowest values recorded in sections of the Pedra and Funil reservoirs and the highest densities in the downstream sections. Nine functional groups were identified (C, F, J, MP, S1, Sn, Td, Y, Ws); of these, F and J grouped the species with the highest relative abundance during the dry season, while the $\mathbf{S 1}$ group, represented by the cyanobacterium Planktothrix agardhii, was dominant in the rainy season. The present study showed a high longitudinal variation in the phytoplankton richness and density, attributed to the hydrological change between the lotic and lentic stretches. Furthermore, the effects of the cascade of reservoirs on phytoplankton, such as reduced density, increased richness and changes in algal associations, were strongly influenced by habitat heterogeneity found in this environment, as well as the rainfall in the region.
\end{abstract}

Keywords: spatial heterogeneity, functional groups, potamoplankton, reservoirs, seasonality.

\section{O papel da cascata de reservatórios e da sazonalidade na variação da estrutura fitoplanctônica em um rio tropical}

\begin{abstract}
Resumo
Este estudo tem como objetivo analisar a influência da cascata de reservatórios sobre a riqueza, a densidade e os grupos funcionais do fitoplâncton em um rio tropical, o Rio de Contas, Bahia, Brasil. Este rio apresenta dois barramentos ao longo do seu curso, os Reservatórios de Pedra e Funil. As coletas foram realizadas durante três anos consecutivos (2007 a 2010), compreendendo os períodos seco (dezembro e março) e chuvoso (junho e setembro), em 28 estações. Foram identificadas 198 espécies fitoplanctônicas, sendo observada maior riqueza nos trechos a jusante dos reservatórios. Chlorophyceae, seguida pelas Bacillariophyceae e Cyanophyceae, foram os grupos dominantes. Maior densidade

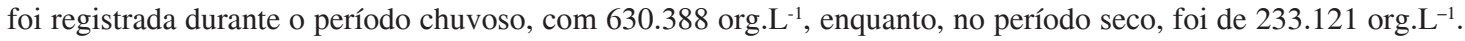
De maneira geral, foi verificado que houve um padrão longitudinal nas densidades das algas em ambos os períodos sazonais, tendo os menores valores sido registrados nos trechos que correspondem aos Reservatórios de Pedra e Funil e as maiores densidades, nos trechos a jusante. Nove grupos funcionais foram identificados (C, F, J, MP, S1, Sn, Td, $\mathbf{Y}, \mathbf{W s}$ ); destes, os grupos $\mathbf{F}$ e $\mathbf{J}$ agruparam as espécies com maiores abundâncias relativas durante o período seco, enquanto o grupo S1, representado pela cianobactéria Planktothrix agardhii (Gomont) Anagnostidis \& Komárek, foi dominante no período chuvoso. O presente estudo mostrou elevada variação longitudinal da riqueza e da densidade, variação esta atribuída à mudança hidrológica entre os trechos lóticos e lênticos. Além disso, os efeitos da cascata de reservatórios sobre o fitoplâncton - como a redução da densidade, o aumento da riqueza e a mudança das associações algais - foram fortemente influenciados pela heterogeneidade de habitats encontrada neste ambiente, assim como pelo regime pluviométrico da região.
\end{abstract}

Palavras-chave: heterogeneidade espacial, grupos funcionais, potamoplâncton, reservatórios, sazonalidade. 


\section{Introduction}

The use of rivers for the construction of reservoirs is a common practice with large Brazilian rivers in an attempt to meet the growing demand for electricity as well as for urban, industrial and agricultural use, including leisure and navigation (Rodgher et al., 2005).

Despite the economic and social importance of reservoirs, their construction causes marked changes in the basins where they are installed, since they disrupt the continuous gradient of the river leading to changes in their physical, chemical and biological characteristics (Zalocar de Domitrovic et al., 2007; Nogueira et al., 2010). When a system of reservoirs is built consecutively, the upstream reservoirs will affect the dynamics of those further downstream, and the set of abiotic and biotic factors in the water accumulate until the last reservoir receives contributions from all the previous water bodies (Barbosa et al., 1999).

The ripple effect can increase when analysing biodiversity, or decrease when focusing on some nutrients, such as, for example, the tendency for longitudinal sedimentation of phosphorus. According to Carol et al. (2006), water quality can be enhanced in systems that are built in series, since the change of condition from lotic to lentic in cascade systems allows the thermal stratification of the dam zone. This is reflected in a flow without heat loss from the system.

Despite the remarkable longitudinal variation of environmental factors in rivers with a cascade of reservoirs, the general pattern is still controversial. Part of this variability may be related to the increase in heterogeneity and complexity that the construction of reservoirs generates in a river. As phytoplankton are good indicators of changes in environmental conditions and are sensitive to potential natural or manmade changes in aquatic ecosystems (Ferreira, 1991; Padisák, 1993; Mathivanan et al., 2007), they are an excellent source for understanding the dynamics of ecosystems in series.

Detailed studies of the influence of cascades of reservoirs on phytoplankton in Brazil are still scarce (Nogueira et al., 2010). Tundisi, 1990 and Pômpeo et al., 1998 showed the occurrence of diatoms in more lotic stations, being replaced by Chlorophyta and cyanobacteria as the water became increasingly transparent due to the sedimentation of particulate nutrients downstream. Barbosa et al. (1999) and Padisák et al. (2000), when studying phytoplankton along a series of reservoirs in the Tietê River, found that community structure was affected by dams along this river. Rodrigues et al. (2009) found that, after the construction of the Porto Primavera Dam on the Paraná river, there was a change in the composition of phytoplankton combined with an increase in phytoplankton densities in the rivers Paraná and Bahia, located immediately downstream from this reservoir. Nogueira et al. (2010) observed the effects of the Paranapanema River on the structure of phytoplankton and pointed out that dams had a negative effect on the richness of these organisms.
Although most studies of ecosystems in series emphasize spatial differences and somehow neglect temporal variability, which is often difficult to understand, seasonality plays an important role in intrinsic processes of the ecosystem. The increase in water level of a river, during the rainy season, increases the flow, while allowing the flooding of surrounding areas usually leads to isolation of these when the water level goes down. The establishment of connectivity, as observed in marginal lagoons or by the activation of temporary tributaries, provides an input of species (Melo and Huszar, 2000; Kudo et al., 2006) and within a context of reservoirs in series may have a new dimension, because longitudinal differences are reflected as ecological barriers for the development of taxa (Reynolds et al., 2002). As these authors suggest, it is common to have differences in the structure and dynamics of communities along the cascade of reservoirs that can be explained by these variations.

Therefore, the aim was to analyse the spatial and seasonal variations of phytoplankton richness and density along a cascade of reservoirs in a tropical river in northeastern Brazil. The study evaluated the role of the cascade of reservoirs and seasonal variation in the structure of phytoplankton in a tropical river, based on the following hypothesis: the existence of a cascade of reservoirs and seasonality influences the structure of the phytoplankton, with increased richness, reduced density and replacement of dominant functional groups along the cascade, with the onset of the rainy season.

\section{Methodology}

The Contas River Basin is one of the basins of the eastern Atlantic and has a total area of $55,000 \mathrm{~km}^{2}$. It is the largest hydrographic basin entirely contained in the state of Bahia, extending in an east-west direction for about $700 \mathrm{~km}$, connecting three biomes: the Cerrado in the Chapada Diamantina (headwater regions), the Caatinga in its middle course, and the Atlantic Forest at its lower course. Its mouth is located in the town of Itacaré $\left(14^{\circ}\right.$ $\left.18^{\prime} \mathrm{S}, 39^{\circ} \mathrm{W}\right)$.

Fuentes et al., 2010 noted that the Contas River is divided into four sections: 1 . Pedra Reservoir with rugged relief, low occupancy on its margins and no perennial tributaries, therefore, a predominantly lentic environment; 2. Downstream from the Pedra Reservoir dam, characterised by the influence of local springs, urban surroundings and for receiving domestic and sanitary sewage. It is a shallow lotic environment; 3. Funil Reservoir, which is predominantly lentic with the presence of many aquatic macrophytes, especially Eichornnia sp. and Egeria densa Planch and urban surroundings; and 4. Downstream from the Funil Reservoir dam to the basin mouth, a lotic stretch under the influence of tributaries.

The climate is predominantly hot, with average annual temperatures around $18{ }^{\circ} \mathrm{C}$ (SEI, 1998). The pluviometric regime consists of a rainy season in summer (November, 
December and January), with peaks in December-January and a dry season in winter (June, July and August).

\subsection{Collection and data analysis}

Samples were collected during three consecutive years (Dec., 2007 to Dec., 2010), comprising the dry (December to March) and rainy (June to September) seasons, at 28 sampling stations distributed along different parts of the river: stations 1-11, Pedra reservoir stretch; stations 12-18, downstream from the Pedra reservoir dam; stations 19-22, Funil reservoir; and stations 23-28, downstream from Funil reservoir to the basin mouth (Figure 1).

Samples were obtained by vertical integrated hauls through the euphotic zone using nets with a mesh of $25 \mu \mathrm{m}$. The extent of the euphotic zone was determined with a quantometer LI-COR (mod. 250). Samples were collected in different vertical strata, from the limit of the euphotic zone to the surface. The phytoplankton samples were stored in amber glass bottles of $250 \mathrm{~mL}$ and preserved with $2 \%$ acetic Lugol.

The phytoplanktonic organisms were analysed under an optical microscope (Zeiss/ Axioskop) and identified to the lowest taxonomic level possible using specialised bibliography. To determine the density (org. $\mathrm{L}^{-1}$ ), we followed Utermöhl (1958). The organisms were quantified throughout the analysis of a complete transect using an inverted microscope Zeiss, model Axiovert 135M, according to Weber (1973).

The relative abundance of algal groups and identified species was calculated from the ratio of the number of different taxa and total taxa in the sample, expressed as a percentage, following Matteucci and Colma (1982). The species with a relative abundance higher than $10 \%$ were grouped into different functional groups based on Reynolds (1997), Reynolds et al. (2002) and Padisák et al. (2009).

\section{Results}

The phytoplankton community of the Contas River was composed of 198 species distributed in 10 classes: Cyanophyceae (17.17\%), Coscinodiscophyceae (7.58\%), Fragilariophyceae (3.54\%), Bacillariophyceae (18.69\%), Chlorophyceae (40.40\%), Euglenophyceae (7.07\%), Cryptophyceae (2.02\%), Chrysophyceae (1.52\%), Dinophyceae (1.52\%) and Xantophyceae (0.51\%).

A total of 161 species were identified in the rainy season and 142 in the dry season, with higher richness, in both periods, in the lotic stretches downstream from the Pedra and Funil reservoirs (Figure $2 \mathrm{a}$ and $\mathrm{b}$ ).

Green algae showed the highest richness in the majority of the sampling stations, throughout both seasons, followed by diatoms and cyanobacteria, to a lesser extent. In the rainy season, the chlorophytes were replaced in richness by diatoms in the Funil reservoir and downstream from it on the third year of monitoring, while in the dry season this substitution occurred in stretches downstream from the Funil reservoir during the three studied years.

The phytoplankton density in the river was highest during the rainy season (630888 org. $\mathrm{L}^{-1}$ ), while in the dry period it was 233121 org. $\mathrm{L}^{-1}$. In general, we observed a longitudinal pattern in density values in both seasons, with lower densities in the sections related to the Pedra and Funil reservoirs (maximum average density of 7100 and 4813 ed. $\mathrm{L}^{-1}$, respectively) and higher densities in

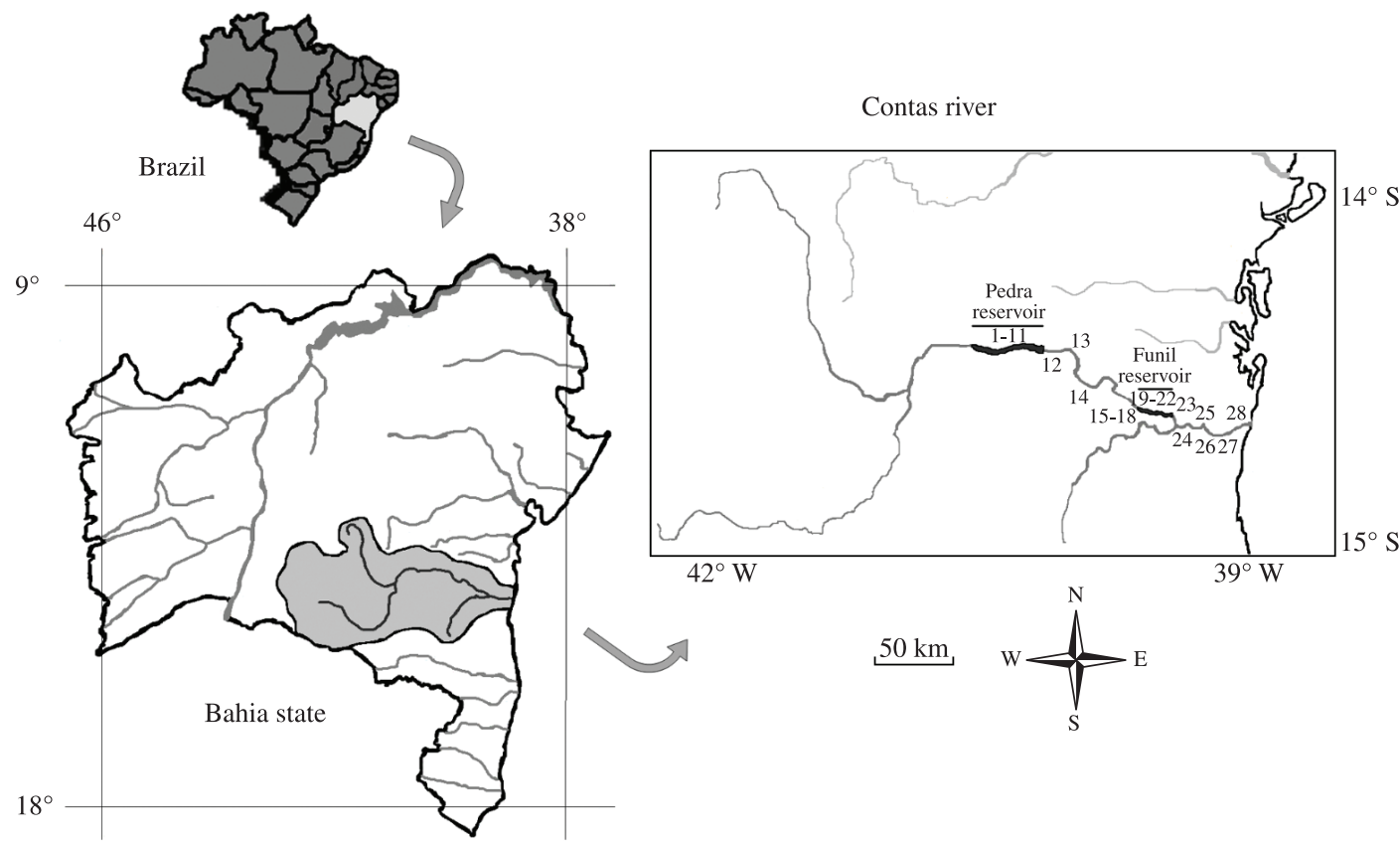

Figure 1. Location of Contas River, Bahia, showing sampling stations. 


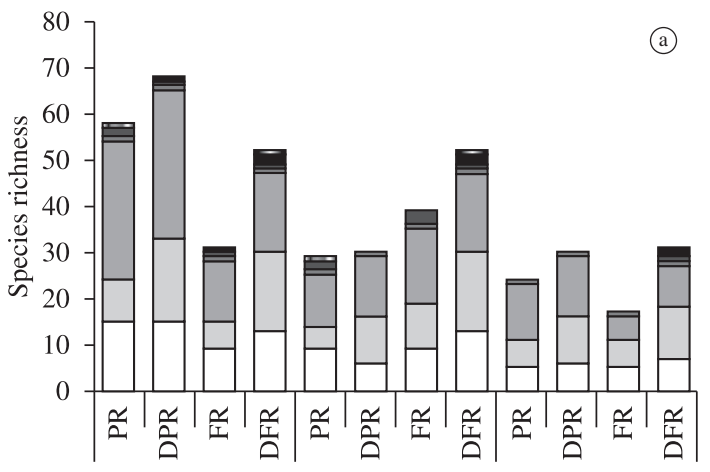

$1^{\text {st }}$ year

$2^{\text {nd }}$ year

$3^{\text {rd }}$ year

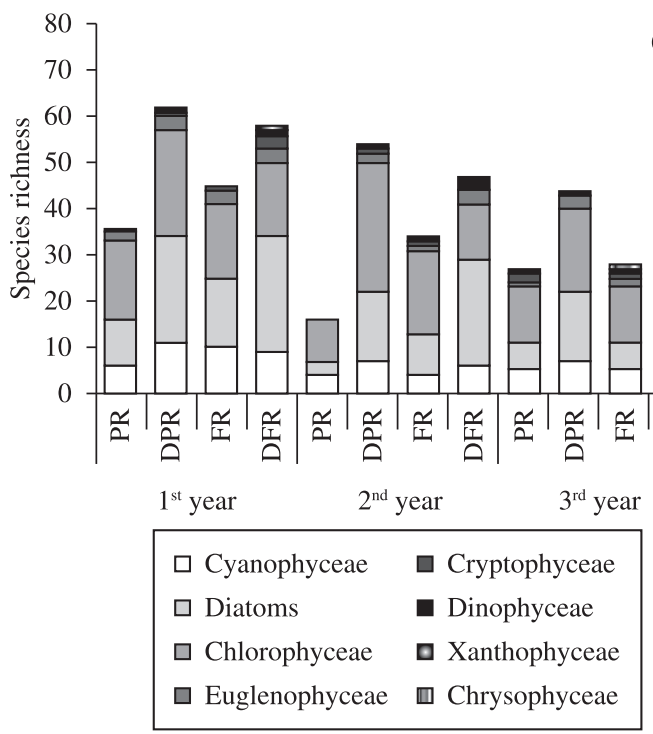

Figure 2. Richness of phytoplankton taxa identified during the rainy (a) and dry (b) seasons in Contas River, Bahia, Brazil. RP = Pedra Reservoir; JRP = Downstream from the Pedra reservoir, $\mathrm{RF}=$ Funil reservoir; JRF $=$ Downstream from the Funil reservoir.

the downstream stretches from these reservoirs (average maximum density of 40991 ed. $\mathrm{L}^{-1}$ downstream from Pedra reservoir and 22067 org. $L^{-1}$ downstream from Funil reservoir) (Figure $3 \mathrm{a}$ and $\mathrm{b}$ ).

In the Pedra reservoir, Chlorophyceae showed the highest densities during the two seasons studied. Downstream from the reservoir during the rainy season, the chlorophytes were replaced by cyanobacteria, with this dominance extending to subsequent sections. In the dry period, diatoms were dominant downstream from the Funil reservoir in the first and second years, while in the third year chrysophyceae showed the highest densities.

Nine phytoplankton functional groups $(\mathbf{C}, \mathbf{F}, \mathbf{J}, \mathbf{M P}$, S1, Sn, Td, Y, Ws) were formed by species with abundance higher than $10 \%$. Three groups were found exclusively in the rainy season $(\mathbf{S 1}, \mathbf{S n}$ and $\mathbf{Y})$ and two groups in the dry season (C and Ws) (Table 1 and 2).
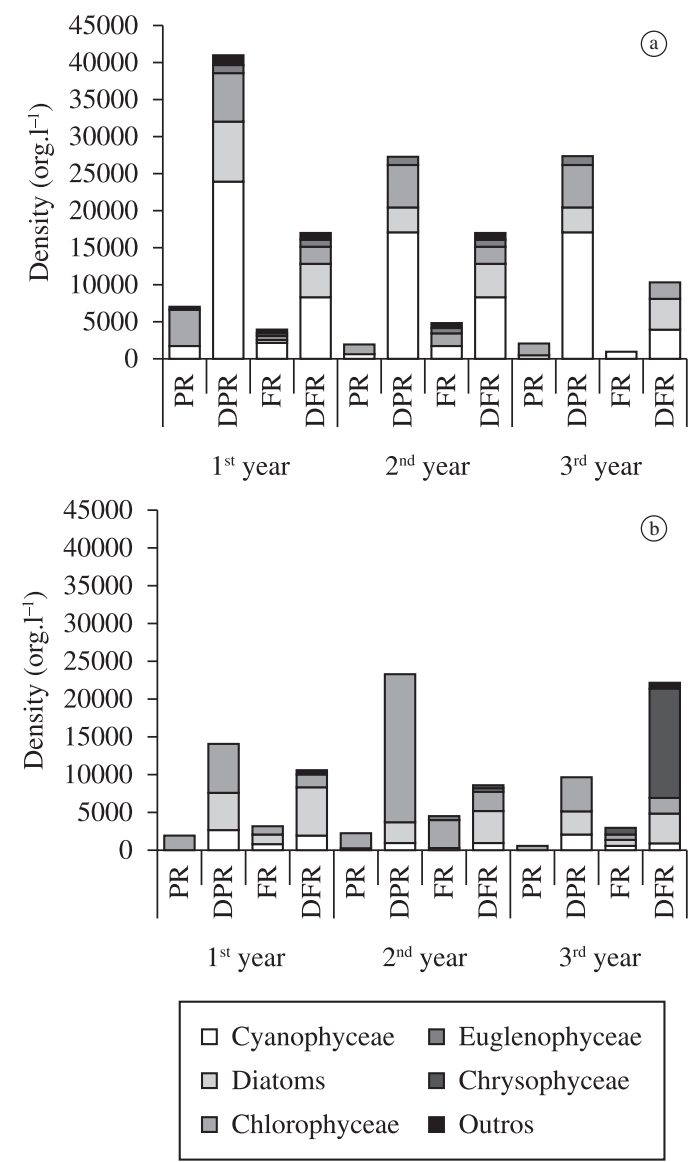

Figure 3. Density of the major taxonomic groups of phytoplankton during the rainy (a) and dry (b) in Contas River, Bahia, Brazil. RP = Pedra Reservoir; JRP $=$ Downstream from the Pedra reservoir, RF $=$ Funil reservoir; JRF $=$ Downstream from the Funil reservoir.

In the Pedra reservoir, during the two sampling periods, the colonial chlorophytes of groups $\mathbf{F}$ (Radiococcus planktonicus J.W.G Lund, Sphaerocystis schroeteri Chodat and Planktosphaeria gelatinosa G. M. Smith) and $\mathbf{J}$ (Coelastrum reticulatum (P. A. Dangeard) Senn) were, quantitatively, the most important ones, sharing this importance with the cyanobacteria (Geitlerinema amphibium (C. Agardh) Anagn.) in group S1 and group Td algae (Spirogyra sp. and Pleurosira laevis (Ehrenberg) Compère) during the rainy and dry seasons, respectively, in the second year of sampling.

In subsequent sections, during the rainy season the functional group $\mathbf{S 1}$, represented by the cyanobacterium Planktothrix agardhii (Gomont) Anagnostidis \& Komarek, was the dominant one. Also, during this period, the cyanobacteria in group $\mathbf{S n}$ (Cylindrospermopsis raciborskii (Woloszynska) Seenaya \& Subba Raju), in the Funil reservoir during the first year of study and in group Td (Pleurosira laevis and Spirogyra sp.), downstream from this reservoir in the third year, were very representative. 
Table 1. Relative contribution (\%) and representatives of the main phytoplankton functional groups identified in the Contas River, Bahia, Brazil, during the rainy season. $\mathrm{RP}=$ Pedra Reservoir; JRP $=$ Downstream from the Pedra reservoir, $\mathrm{RF}=\mathrm{Funil}$ reservoir; JRF = Downstream from the Funil reservoir.

\begin{tabular}{|c|c|c|c|c|c|c|c|c|c|c|c|c|c|}
\hline \multirow{2}{*}{$\begin{array}{c}\text { Functional } \\
\text { group }\end{array}$} & \multicolumn{4}{|c|}{$\mathbf{1}^{\text {st }}$ year } & \multicolumn{4}{|c|}{$2^{\text {nd }}$ year } & \multicolumn{4}{|c|}{$3^{\text {rd }}$ year } & \multirow{2}{*}{$\begin{array}{c}\text { Main representatives } \\
\text { species }\end{array}$} \\
\hline & $\mathbf{R P}$ & JRP & RF & JRF & $\mathbf{R P}$ & JRP & RF & JRF & $\mathbf{R P}$ & JRP & RF & JRF & \\
\hline $\mathrm{J}$ & 34.66 & 3.56 & 0.00 & 0.88 & 35.63 & 0.39 & 4.43 & 0.88 & 0.68 & 0.39 & 0.00 & 0.00 & Coelastrum reticulatum \\
\hline $\mathrm{F}$ & 44.97 & 5.44 & 0.96 & 3.52 & 26.43 & 9.29 & 4.10 & 3.52 & 52.35 & 9.29 & 0.00 & 2.91 & $\begin{array}{l}\text { Planktosphaeria } \\
\text { gelatinosa and } \\
\text { Sphaerocystis } \\
\text { schroeteri }\end{array}$ \\
\hline MP & 0.72 & 1.51 & 0.00 & 0.00 & 0.00 & 0.38 & 4.10 & 0.00 & 20.47 & 0.38 & 2.08 & 0.53 & Ulnaria ulna \\
\hline S1 & 7.80 & 74.82 & 43.38 & 64.83 & 36.01 & 72.66 & 74.13 & 64.83 & 19.42 & 72.66 & 70.34 & 35.16 & $\begin{array}{l}\text { Geitlerinema } \\
\text { amphibium, } \\
\text { Planktothrix agardhii } \\
\text { and Pseudanabaena } \\
\text { limnetica }\end{array}$ \\
\hline $\mathrm{Sn}$ & 3.79 & 0.20 & 34.55 & 11.87 & 1.26 & 1.67 & 2.02 & 11.87 & 7.07 & 1.67 & 24.97 & 4.50 & $\begin{array}{l}\text { Cylindrospermopsis } \\
\text { raciborskii }\end{array}$ \\
\hline $\mathrm{Td}$ & 1.44 & 9.88 & 1.92 & 9.32 & 0.00 & 15.61 & 0.00 & 9.32 & 0.00 & 15.61 & 2.60 & 56.90 & $\begin{array}{l}\text { Pleurosira laevis and } \\
\text { Spirogyra } \mathrm{sp.}\end{array}$ \\
\hline Y & 6.63 & 4.60 & 19.19 & 9.58 & 0.68 & 0.00 & 11.23 & 9.58 & 0.00 & 0.00 & 0.00 & 0.00 & Cryptomonas ovata \\
\hline
\end{tabular}

Table 2. Relative contribution (\%) and representatives of the main phytoplankton functional groups identified in the Contas River, Bahia, Brazil, during the dry season. $\mathrm{RP}=$ Pedra Reservoir; JRP $=$ Downstream from the Pedra reservoir, $\mathrm{RF}=\mathrm{Funil}$ reservoir; JRF $=$ Downstream from the Funil reservoir.

\begin{tabular}{|c|c|c|c|c|c|c|c|c|c|c|c|c|c|}
\hline \multirow{2}{*}{$\begin{array}{l}\text { Functional } \\
\text { group }\end{array}$} & \multicolumn{4}{|c|}{$1^{\text {st }}$ year } & \multicolumn{4}{|c|}{$2^{\text {nd }}$ year } & \multicolumn{4}{|c|}{$3^{\text {rd }}$ year } & \multirow{2}{*}{$\begin{array}{c}\text { Main representatives } \\
\text { species }\end{array}$} \\
\hline & $\mathbf{R P}$ & JRP & RF & JRF & $\mathbf{R P}$ & JRP & RF & JRF & $\mathbf{R P}$ & JRP & RF & JRF & \\
\hline $\mathrm{C}$ & 0.14 & 1.74 & 25.16 & 6.38 & 0.00 & 0.17 & 0.69 & 16.44 & 0.58 & 35.42 & 44.39 & 5.22 & Cyclotella meneghiniana \\
\hline $\mathrm{F}$ & 10.82 & 28.17 & 36.60 & 15.50 & 22.14 & 10.23 & 15.09 & 35.06 & 79.97 & 39.22 & 14.53 & 3.09 & $\begin{array}{l}\text { Oocystis sp., } \\
\text { Planktosphaeria } \\
\text { gelatinosa, Radiococcus } \\
\text { planktonicus and } \\
\text { Sphaerocystis schroeteri }\end{array}$ \\
\hline $\mathrm{J}$ & 88.68 & 34.75 & 1.03 & 2.21 & 36.13 & 84.90 & 83.56 & 13.49 & 11.38 & 9.54 & 0.57 & 0.19 & $\begin{array}{l}\text { Actinastrum gracillimum, } \\
\text { Coelastrum reticulatum } \\
\text { and Scenedesmus } \\
\text { acuminatus }\end{array}$ \\
\hline MP & 0.36 & 0.93 & 25.59 & 4.15 & 0.00 & 0.17 & 0.00 & 0.00 & 0.00 & 0.00 & 0.00 & 0.39 & Navicula sp. \\
\hline $\mathrm{Td}$ & 0.00 & 34.41 & 11.62 & 71.76 & 41.73 & 4.53 & 0.66 & 35.01 & 8.07 & 15.82 & 0.00 & 6.77 & $\begin{array}{l}\text { Pleurosira laevis and } \\
\text { Spirogyra } \mathrm{sp.}\end{array}$ \\
\hline Ws & 0.00 & 0.00 & 0.00 & 0.00 & 0.00 & 0.00 & 0.00 & 0.00 & 0.00 & 0.00 & 40.51 & 84.33 & Synura sp. \\
\hline
\end{tabular}

In the dry period, the groups $\mathbf{F}$, formed by Oocystis sp., P. gelatinosa, R. planktonicus and S. schroeteri, and $\mathbf{J}$, formed by Actinastrum gracillimum Smith, C. reticulatum and Scenedesmus acuminatus (Lagerheim) Chodat, were the most representative downstream from the Pedra reservoir, with the exception of the third year, where there was a co-dominance between the $\mathbf{F}$ and $\mathbf{C}$ groups (diatom Cyclotella meneghiniana Kützing). In the Funil reservoir, the dominant functional groups varied over the study years, with a higher contribution of groups $\mathbf{C}, \mathbf{F}$ and $\mathbf{M P}$ (Navicula sp.) in the first year, group $\mathbf{J}$ in the second year and groups $\mathbf{C}$ and Ws (Chrysophyceae Synura sp.) in the third year of monitoring. The same occurred downstream from the Funil reservoir, with dominance of group Td in the first year, co-dominance of groups $\mathbf{F}$ and $\mathbf{T d}$ in the second year, and group Ws in the third.

\section{Discussion}

The Contas river presented spatial and temporal variations of phytoplankton richness and density. The greatest richness and algal densities were recorded in 
lotic stretches during the rainy season. The discontinuity between the lotic and lentic stretches in richness and density values was related to hydrological changes, habitat specificity and seasonality. In general, the cascade of reservoirs contributed to a longitudinal density reduction and an increase in the algal richness, which was more pronounced during the dry period.

Studies in rivers that have a cascade of reservoirs have shown that dams influence the structure and dynamics of the algal community. In the Contas River, the dams caused changes in phytoplankton richness, with a greater number of species in sites downstream from the Pedra and Funil reservoirs. This confirms the findings of Nogueira et al. (2010), that a greater number of taxa in the Paranapanema River were associated with the (unregulated) fluvial river stretches.

The increase in richness downstream is considered standard as, in rivers, these sections act as a species deposit from tributaries and from the upstream sections, which validates the understanding of the downstream ecosystems as biodiversity depositories.

The structure of the phytoplankton community in the Contas River presented evident spatial and temporal variations. The seasonal variation was verified, mainly, through the high density during the rainy season compared to the dry one. During the rainy season there is a greater carriage of nutrients and suspended matter, because the contribution of the river is more intense, which enables the development of phytoplankton. This demonstrates the role of rainfall on phytoplankton dynamics, which can be considered the main factor affecting these organisms.

Unlike this study, others have reported higher phytoplankton densities during the dry season (Teixeira de Oliveira et al., 2011), indicating that an increase in light availability and reduced water flow, observed during this period, may also be important factors that favour the development of phytoplankton.

Spatial variations were expressed by differences in the structure of the phytoplankton community in different parts of the river. The section that corresponds to the Pedra reservoir was characterised by low density values, the community being formed especially by colonial green algae of groups $\mathbf{F}$ and $\mathbf{J}$ in both seasons. Low levels of human impact on the site, due to reduced occupancy in its surroundings, coupled with the absence of perennial tributaries, was reflected in the structural homogeneity of the phytoplankton.

Groups $\mathbf{F}$ and J, according to Reynolds et al. (2002) and Padisák et al. (2009), have different environmental requirements and, therefore, are not commonly found co-dominating in water bodies. Group $\mathbf{F}$ is found in light epilimnion environments, with low nutrient concentration and high turbidity, while group $\mathbf{J}$ inhabits shallow, mixed and highly enriched environments.

Becker et al. (2010) analysed the factors (light, mixing regime, nutrients) that control the dynamics of phytoplankton functional groups in the Sau reservoir, northeast of Spain, and noted that group $\mathbf{F}$ was dominant in summer, during the period in which the system had a mixing area with a $70 \%$ average brightness and a nutrient deficiency.

In the Contas River, the chlorophytes of groups $\mathbf{F}$ and $\mathbf{J}$ also showed numerical contributions in the dry season in the downstream stretches from Pedra, but were replaced during the rainy season by the filamentous cyanobacterium Planktothrix agardhii (group S1) that reached high densities, especially in lotic stretches.

The increased density downstream from the Pedra reservoir can be associated with an increase in human influence in this section, due to the presence of large urban centers in the vicinity, which may cause the increase in the inflow of domestic and sanitation sewage, as shown by Fuentes et al. (2010).

Several studies have reported increased phytoplankton density, especially cyanobacteria, due to the discharge of nutrients into water bodies (Pizzolon et al., 1999; Nogueira et al., 2010). High densities of potamoplankton have been recorded in eutrophic rivers during periods of lower discharge and slower water flow (Grabowska and Mazur-Marzec, 2011). However, cyanobacterial blooms typically occur in lakes and reservoirs, which have created major social, economic and environmental problems.

The presence of group $\mathbf{S 1}$ is indicative of eutrophic or high trophic level environments. This was verified by Hajnal and Padisák (2008), when using phytoplankton association as indicators of trophic changes in the ecosystem, noting that group $\mathbf{S} 1$ cyanobacteria were dominant in low quality water conditions.

Rücker et al. (1997) found that shallow, turbulent environments, with high temperatures and high nitrate concentrations, as evidenced by the discharge of sewage in ecosystems, were the main factors that favored the dominance of $P$. agardhii in German lakes.

The reduction in density values in the Funil reservoir may reflect the presence of aquatic macrophytes that affect the structure and dynamics of the phytoplankton community in different ways: competition for nutrients with phytoplankton; an increase in grazing pressure on phytoplankton, as they provide refuge for zooplankton from fish predation; and a decrease in light penetration in the water column causing reduced light conditions for the phytoplankton community (Schriver et al., 1995; Lau and Lane, 2002; Bicudo et al., 2007; O'Farrell et al., 2007; Fonseca and Bicudo, 2010). Pinto et al. (2007) analysed the influence of floating plants on the phytoplankton structure and found that the presence of macrophytes limited the growth of these organisms and influenced the formation of phytoplankton functional groups. The authors observed that in the presence of macrophytes, slow growth cyanobacteria from groups $\mathbf{S}$ and Lo were dominant, while in the absence of macrophytes these groups had been replaced by unicellular green algae (group X1 and X2) and rapid growth picophytoplankton (X3).

The group Ws was dominant downstream from the Funil reservoir during the dry period, especially in the third year of monitoring. This group was created by Padisák et al. (2003) to include the Synura species, 
which are sensitive to high light radiation and tolerant to environments rich in organic matter from plant decay. In the Funil reservoir, the increase in Ws may have been the product of a greater decomposition of macrophytes that should have happened in this investigation year, as the existence of this community formed extensive banks in this stretch (Fuentes et al., 2010). Isolated reports of phytoflagellate blooms may be indicative of a longitudinal nutrient reduction by establishing favorable conditions for mixotrophy (Reynolds et al., 2002). Mixotrophic organisms are those able to produce their own food through photosynthesis, but which may also feed on other organic compounds (heterotrophy).

Also in this section, dominance of the diatom Pleurosira laevis (group Td) was observed. The substantial increase of this taxon is probably due to the greater influence of the estuary of the Contas River on this section, since diatoms are known to contain the most important estuarine phytoplankton algae, often representing more than $80 \%$ of all groups. Patrick (1967) and Egge and Ansnes (1992) attribute the dominance of this group to its high growth rate compared to other phytoplankton groups, but also to its euryhaline nature and its preference for eutrophic environments, unique estuarine ecosystems.

\section{Conclusions}

The present study demonstrated a wide variation of longitudinal patterns in phytoplankton richness and density. However, these variations are directly related to hydrological change, with higher values in the lotic stretches. In general, the effects of the cascade contributed to a longitudinal reduction in density both in the reservoirs and in the lotic sections, being more pronounced during the dry period. The effects of the cascade were favourable to increase in richness only in the reservoirs, especially during the dry season. The variations in density along the Contas River could be explained by different algal associations that were strongly influenced by habitat heterogeneity found in this environment, as well as the rainfall in the region. The $\mathbf{J}$ and $\mathbf{F}$ chlorophyta were dominant in the first dam, independent of seasonal period. Cyanobacteria $\mathbf{S 1}$ were dominant downstream from the first dam in the rainy season, in stretches with higher nutrient availability. In the dry season, the downstream sections showed dominance of chlorophyta $\mathbf{J}$ and diatoms $\mathbf{C}$, in stretches of higher nutrient availability, phytoflagellates Ws, in stretches with the presence of macrophytes and diatoms $\mathbf{T d}$ related to sections under estuarine influence.

Acknowledgements - This study was supported by grants from CNPQ (Proc. 301715/2008-4) - the Brazilian agency for the promotion of Science.

\section{References}

BARBOSA, FAR., PADISÁK, J., ESPÍNDOLA, ELG., BORICS, G. and ROCHA, O., 1999. The cascading reservoir continuum concept (CRCC) and its application to the river Tietê-basin,
São Paulo State, Brazil. In TUNDISI, JG. and STRASKRABA, M. (Eds.). Theoretical Reservoir Ecology and its Applications. Leiden: Brazilian Academy of Sciences, International Institute of Ecology and Backhuys Publishers. p. 425-437.

BECKER, V., CAPUTO, L., ORDÓÑEZ, J., MARCÉ, R., ARMENGOL, J., CROSSETTI, LO. and HUSZAR, VLM., 2010. Driving factors of the phytoplankton functional groups in a deep Mediterranean reservoir. Water Research, vol. 44, no. 11, p. 33453354. http://dx.doi.org/10.1016/j.watres.2010.03.018

BICUDO, DC., FONSECA, BM., BINI, LM., CROSSETTI, LO., BICUDO, CEM. and ARAÚJO-JESUS, T., 2007. Undesirable side-effects of water hyacinth control in a shallow tropical reservoir. Freshwater Biology, vol. 52, no. 6, p. 1120-1133. http://dx.doi. org 10.1111/j.1365-2427.2007.01738.x

CAROL, J., BENEJAM, L., ALCARAZ, C., VILA-GISPERT, A., ZAMORA, L., NAVARRO, E., ARMENGOL, J. and GARCÍABERTHOU, E., 2006. The effects of limnological features on fish assemblages of 14 Spanish reservoirs. Ecology of Freshwater Fish, vol. 15, no. 1, p. 66-77. http://dx.doi.org/10.1111/j.16000633.2005.00123.x

EGGE, JK. and AKSNES, DL., 1992. Silicate as regulating nutrient in phytoplankton competition. Marine Ecology Progress Series, vol. 83, p.281-289. http://dx.doi.org/10.3354/meps083281

FERREIRA, MT., 1991. Use of algae for monitoring rivers in Portugal. In WHITTON, BA., ROTT, E. and FRIEDRICH, G. (Eds.) Use of algae for monitoring rivers. Universität Innsbruck, Institut für Botanik. p. 145-150.

FONSECA, BM. and BICUDO, CEM., 2010. How important can the presence/absence of macrophytes be in determining phytoplankton strategies in two tropical shallow reservoirs with different trophic status? Journal of Plankton Research, vol. 32, no. 1, p. 31-46. http://dx.doi.org10.1093/plankt/fbp107

FUENTES, EV., OLIVEIRA, HSB., CORDEIRO-ARAÚJO, MK., SEVERI, W. and MOURA, AN., 2010. Variação espacial e temporal do fitoplâncton do rio de Contas,Bahia, Brasil. Revista Brasileira de Engenharia de Pesca, vol. 5, no. 2, p. 13-25.

GRABOWSKA, M. and MAZUR-MARZEC, H., 2011. The effect of cyanobacterial blooms in the Siemianówka Dam Reservoir on the phytoplankton structure in the Narew River. Oceanological and Hydrobiological Studies, vol. 40, no. 1, p. 19-26. http://dx.doi. org/10.2478/s13545-011-0003-X

HAJNAL, E. and PADISÁK, J., 2008. Analysis of long-term ecological status of Lake Balaton based on the ALMOBAL phytoplankton database. Hydrobiologia, vol. 599, no. 1, p. $227-$ 237. http://dx.doi.org 10.1007/s10750-007-9207-x

KUDO, FA., JORCIN, A. and NOGUEIRA, MG., 2006. Composição e distribuição da comunidade zoobentônica em áreas de várzea do rio Paranapanema (SP/PR). In NOGUEIRA, MG., HENRY, R. and JORCIN, A. (Eds.). Ecologia de reservatórios - impactos potenciais, ações de manejo e sistemas em cascata. São Carlos: Rima. p. 379-416.

LAU, SSS. and LANE, SN., 2002. Nutrient and grazing factors in relation to phytoplankton level in a eutrophic shallow lake: the effect of low macrophyte abundance. Water Research, vol. 36, no. 14, p. 3593-3601. http://dx.doi.org/10.1016/S0043-1354(02)00059-3

MATTEUCCI, SD. and COLMA, A., 1982. Metodología para el estudio de la vegetación. Washington: Secretaria General de la Organización de los Estados Americanos (Programa Regional de Desarrollo Cientifico y Tecnológico, Washington). 
MATHIVANAN, V., VIJAYAN, P., SABHANAYAKAM, S. and JEYACHITRA, O., 2007. An assessment of plankton population of Cauvery river with reference to pollution. Journal of Environmental Biology, vol. 28, no. 2, p. 523-526.

MELO, S. and HUSZAR, VLM., 2000. Phytoplankton in an Amazonian flood-plain lake (Lago Batata, Brazil): diel variation and species strategies. Journal of Plankton Research, vol. 22, no. 1, p. 63-76. http://dx.doi.org/10.1093/plankt/22.1.63

NOGUEIRA, MG., FERRAREZE, M., MOREIRA, ML. and GOUVÊA, RM., 2010. Phytoplankton assemblages in a reservoir cascade of a large tropical - subtropical river (SE, Brazil). Brazilian Journal of Biology, vol. 70, no. 3, p. 781-793. http:// dx.doi.org/10.1590/S1519-69842010000400009

O'FARRELL, I., PINTO, PT. and IZAGUIRRE, I., 2007. Phytoplankton morphological response to the underwater light conditions in a vegetated wetland. Hydrobiologia, vol. 578, no. 1, p. 65-77. http://dx.doi.org/10.1007/s10750-006-0434-3

PADISÁK, J. 1993. Use of algae for water quality monitoring. In SALÁNKI, J. and ISTVÁNOVICS, V. (Eds.). Limnological bases of Lake Management. Shiga: Committee Foundation. p. 73-82.

PADISÁK, J., BARBOSA, FAR., BORBÉLY, G., BORICS, G., CHORUS, I., ESPINDOLA, ELG., HEINZE, R., ROCHA, O., TÖRÖKNÉ, AK. and VASAS, G., 2000. Phytoplankton composition, biodiversity and a pilot survey of toxic cyanoprokaryotes in a large cascading reservoir system (Tietê basin, Brazil). Verhandlungen des Internationalen Verein Limnologie, vol. 27, p. 2734-2742.

PADISÁK, J., BORICS, G., FEHÉR, G., GRIGORSZKY, I., OLDAL, I., SCHMIDT, A. and ZÁMBÓNÉ-DOMA, Z., 2003. Dominant species, functional assemblages and frequency of equilibrium phases in late summer phytoplankton assemblages in Hungarian small shallow lakes. Hydrobiologia, vol. 502, no. 1-3, p. 157168. http://dx.doi.org/10.1023/B:HYDR.0000004278.10887.40

PADISÁK, J., CROSSETTI, LO. and NASELLI-FLORES, L., 2009. Use and misuse in the application of the phytoplankton functional classification: a critical review with updates. Hydrobiologia, vol. 621, no. 1, p. 1-19. http://dx.doi.org/10.1007/s10750-008-9645-0

PATRICK, R., 1967. Diatoms communities in estuaries. In LAUFF, G.H. (Ed.). Estuaries. Washington: American Association for the Advancement of Science. p. 311-315.

PIZZOLON, L., TRACANNA, B., PRÓSPERI, C. and GUERRERO, JM., 1999. Cyanobacterial blooms in Argentinean inland waters. Research and Management, vol. 4, p. 101-105.

PINTO, PT., ALLENDE, L.and O'FARRELL, I., 2007. Influence of free-floating plants on the structure of a natural phytoplankton assemblage: an experimental approach. Journal of Plankton Research, vol. 29 , p. 47-56

POMPÊO, MLM., MOSCHINI-CARLOS, V., COSTA-NETO, JP., CAVALCANTE, PRS., IBAÑEZ, MSR., FERREIRA-CORREIA, MM. and BARBIERI, R., 1998. Heterogeneidade espacial do fitoplâncton no reservatório de Boa Esperança (Maranhão - Piauí, Brasil). Acta Limnologica Brasiliensia, vol. 10, p. 101-113.

REYNOLDS, CS., 1997. Vegetation processes in the pelagic: a model for ecosystem theory. Oldendorf: Ecology Institute.
REYNOLDS, CS., HUSZAR, V., KRUK, C., NASELLI-FLORES, L. and MELO, S., 2002. Towards a functional classification of the freshwater phytoplankton. Journal of Plankton Research, vol. 24, p. 417-428. http://dx.doi.org/10.1093/plankt/24.5.417

RODRIGUES, LC., TRAIN, S., BOVO-SCOMPARIN, VM., JATI, S., BORSALLI, CCJ. and MARENGONI, E., 2009. Inter annual variability of phytoplankton in the main rivers of the Upper Paraná River floodplain, Brazil: influence of upstream reservoirs. Brazilian Journal of Biology, vol. 69, no. 2, Supplement, p. 501-516. http:// dx.doi.org/10.1590/S1519-69842009000300006

RODGHER, S., ESPÍNDOLA, ELG., ROCHA, O., FRACÁCIO, R., PEREIRA, RHG. and RODRIGUES, MHS., 2005. Limnological and ecotoxicological studies in the cascade of reservoirs in the Tietê River (São Paulo, Brazil). Brazilian Journal of Biology, 65, no. 4, p. 697-710. http://dx.doi.org/10.1590/S1519-69842005000400017

RÜCKER, J., WIEDNER, C. and ZIPPEL, P., 1997. Factors controlling the dominance of Planktothrix agardhii and Limnothrix redeckei in eutrophic shallow lakes. Hydrobiologia, vol. 342-43, p.107-15. http://dx.doi.org/10.1023/A:1017013208039

SCHRIVER, P., BØESTRAND, J., JEPPENSEN, E. and SØNDERGAARD, M., 1995. Impact of submerged macrophytes on fish-zooplankton-phytoplankton interactions: large-scale enclosure experiments in a shallow eutrophic lakes. Freshwater Biology, vol. 33, no. 2, p. 255-270. http://dx.doi.org/10.1111/j.1365-2427.1995. tb01166.x

Superintendência de Estudos Econômicos e Sociais da Bahia - SEI, 1998. Análise dos atributos climáticos do Estado da Bahia. Salvador: Governo do Estado da Bahia Secretaria do Planejamento, Ciência e Tecnologia, Superintendência de Estudos Econômicos e Sociais da Bahia. Série Estudos e Pesquisas. p. 38-85.

TEIXEIRA DE OLIVEIRA, M., ROCHA, O. and PERET, AC., 2011. Structure of the phytoplankton community in the Cachoeira Dourada reservoir (GO/MG), Brazil. Brazilian Journal of Biology, vol. 71, no. 3, p. 587-600. http://dx.doi.org/10.1590/ S1519-69842011000400003

TUNDISI, JG., 1990. Perspectives for ecological modeling of tropical and subtropical reservoirs in South America. Ecological Modelling, vol. 52, p.7-20. http://dx.doi.org/10.1016/03043800(90)90003-Y

UTERMÖHL, H., 1958. Zur Vervollkommung der quantitativen Phytoplanktonmethodik. Mitteilung Internationale Vereinigung fuer Theoretische unde Amgewandte Limnologie, vol. 9, p.1-38.

WEBER, CI., 1973. Biological field and laboratory methods for measuring the quality of surface waters and efluents. EPA670/4-73-001. Cincinnati: National Environmental Research Center, Oficce of Research and Development, U.S. Environmental Protection Agency.

ZALOCAR DE DOMITROVIC, Y., POI DE NEIFF, ASG. and CASCO, SL., 2007. Abundance and diversity of phytoplankton in the Paraná River (Argentina) $220 \mathrm{~km}$ downstream of the Yacyretá reservoir. Brazilian Journal of Biology, vol. 67, no. 1, p. 53-63. http://dx.doi.org/10.1590/S1519-69842007000100008 